
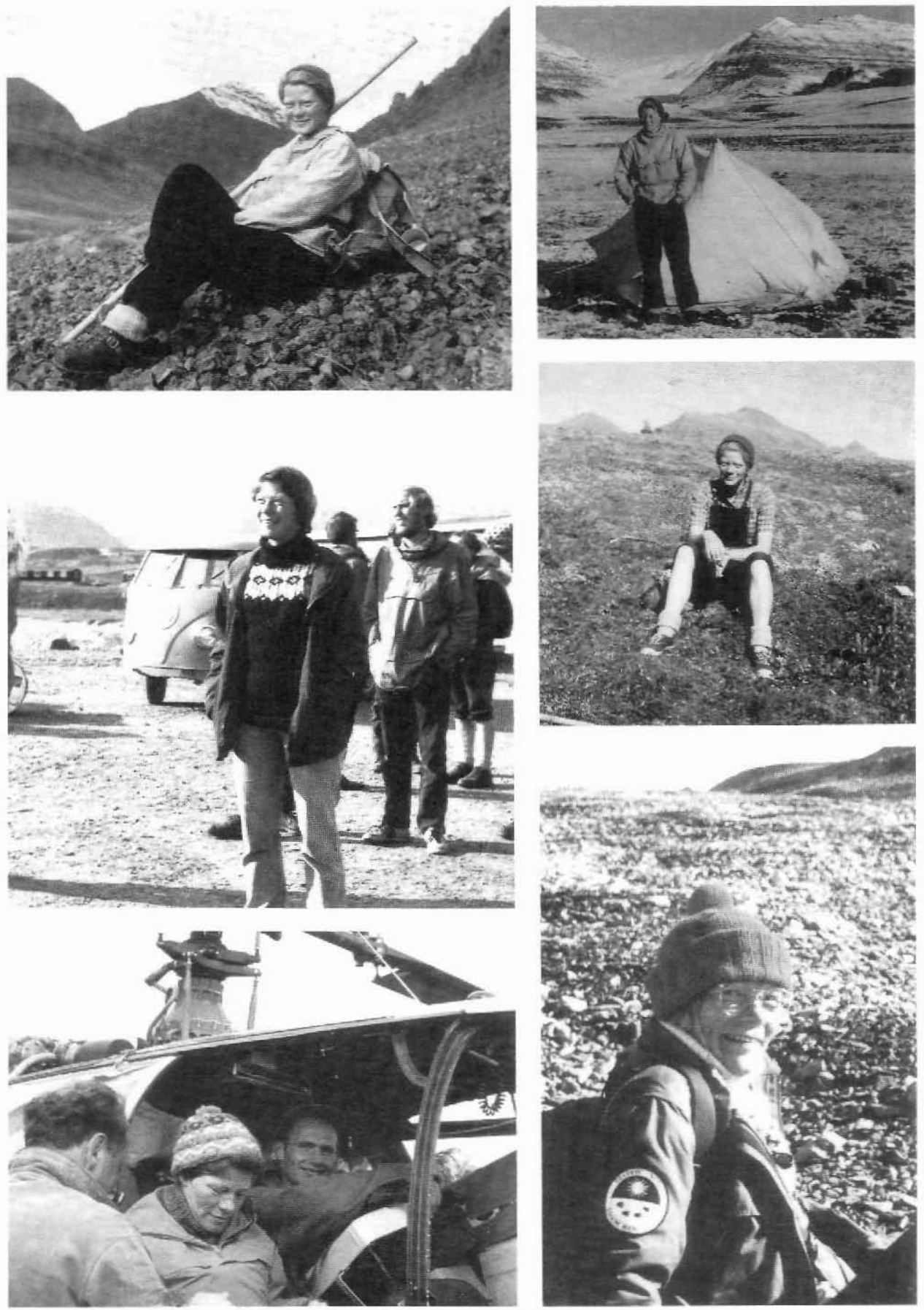

Fig. 1. Tove Birkelund in Greenland, 1952-85. (Photographs: A. Rosenkrantz, N. Henriksen, F. Surlyk, S. Schack Pedersen.) 


\section{Tove Birkelund}

During the editing of this volume it was announced that Professor Tove Birkelund had died in Copenhagen on 24th June 1986 at the early age of 57 years. Tove Birkelund was for several decades a central figure in Greenland geology, maintaining an involvement with Greenland begun during her earliest days as a geologist. Although employed by the University of Copenhagen, her work in Greenland was at all times closely associated with GGU.

Her Greenland career started in the Nûgssuaq region of West Greenland as a member of GGU expeditions led by Professor Alfred Rosenkrantz. At that time, in the late forties and early fifties, only few women participated in field work in Greenland, but Tove quickly showed the devotion to field geology that she kept all her life. Over the years she spent several full field seasons in Greenland, first in West Greenland and later in the Scoresby Sund region of East Greenland. Her last field season was in easternmost North Greenland where she joined an expedition funded by the Carlsberg Foundation to Kilen in Kronprins Christian Land in 1985.

Tove Birkelund's contribution to Greenland geology was mainly in the field of Mesozoic stratigraphy and palaeontology. Her doctoral thesis from 1965 on Upper Cretaceous ammonites from West Greenland was based on collections from 'The Danish Nûgssuaq Expeditions 1938-39'. This study heralded her future status as an internationally recognised ammonite specialist with a background in detailed studies of the Middle and Upper Jurassic faunas from East Greenland. In this work she maintained a fruitful co-operation with John $\mathrm{H}$. Callomon (University of London) which continued up to her death.

When GGU began its major mapping project in the Scoresby Sund region in 1968, Tove accepted the responsibility of leading the studies of post-Caledonian sediments. She formed a working group of young geologists and students at the University who during the next decade undertook geological mapping and regional investigations in Jameson Land and Milne Land. Tove was an inspiring leader, both in the field and in the laboratory, and always succeeded in combining the scientific aspects of the work-in-hand with the more practical demands of geological surveying.

Tove was for many years a member of various Danish scientific committees, steering groups, advisory boards and foundations and in this role she was able to exert considerable influence on the development of geological research in Greenland. In later years this work took an increasing part of her time, but her continued personal research gave her clear insight into the requirements of the active scientist and the basic need for proper research policies.

Tove Birkelund will be missed both as a geologist and as an instigator of geological research. In addition, many of us will miss her as a charming and lively expedition companion who, in spite of her leading role in the recent development of the science in Denmark, was always eager to participate on equal terms with all others in field work in Greenland. 